19

\title{
U.S. CIVILIAN ARCHITECTURE FOR STABILIZATION AND COUNTERINSURGENCY IN NORTHERN AFGHANISTAN (2012-2013)
}

Keith Mines

While attending the loya jirga (grand council) during my first State Department tour in Afghanistan in the spring of 2002, I befriended a grizzled but young ex-mujahidin fighter from the mountain village of Gayan on the Pakistani border. Arif was a man of the land whose focus was prayer, farming, and fighting. He could have been transported back 100 years and life would have been little different.

We saw each other several times over the next month and developed a close friendship. He was both curious and hopeful about these foreigners who had appeared, seemingly out of nowhere, and he summarized for me a good deal of what would play out for the next decade: anger over civilian casualties, a periphery almost completely cut off from the center, fierce factional and ethnic conflict, a flat economy, and a willingness and ability of local forces to fight the central government when developments did not go their way. It indicated a good deal of work ahead for the reborn nation, an observation a female delegate to the loya jirga expressed when she answered the question "What do you need?" by simply saying, "We need everything."

The international coalition anxiously sought to provide a new beginning for Afghanistan, acting under the self-interested notion that a stable Afghanistan would fend off the kinds of intrusions that allowed international terrorists safe haven in the lead up to the $9 / 11$ attacks. From the earlier concept of Afghanistan as a platform from which Western forces would be able to pursue al-Qaida, the model that gradually emerged was one of a partner that would contain terrorism through its own capacity.

For a country starting from such a low bar, it was to be a long-term, resource-intensive project across the three standard counterinsurgency lines of effort: economy, security, and governance. ${ }^{1}$ The size of the required effort brought in much of the international community, and on the U.S. side nearly the whole of the interagency. This chapter provides a snapshot of this capacity-building effort from the perspective of the author's experience while serving as the senior U.S. State Department official in Mazar-i-Sharif from 2012-2013 and offers several lessons about civil-military cooperation.

\section{Diplomatic field architecture}

By statute, the U.S. Department of State takes the lead on the civilian side of a stabilization effort under the direction of an ambassador. Most civilian employees (and uniformed service members not under a 
major command such as U.S. Central Command) fall under the ambassador's authority, and their presence in country is with his or her approval. Significant military efforts fall directly under the combatant commander, but military commanders coordinate closely with the ambassador, and successful ambassadors and commanders go to great lengths to ensure their lines of effort are fully synchronized. There is by now a well-understood principle that any discord between the ambassador and military leadership, or among their respective subordinates, is a recipe for disaster.

A good part of the State Department's role overseas is managing the U.S. platform itself: the embassy if in a capital, or consulate or "regional platform" if outside the capital. The State Department's management branch is staffed and resourced to provide a secure location from which outreach, reporting, and programs can be safely and productively supported. In a country as geographically inaccessible as Afghanistan, policymakers saw the need to extend the embassy's reach into the country's regions even beyond consulates, where issues could be more directly managed.

U.S. Ambassador Ryan Crocker, who led the U.S. mission from 2011-2012, told me there was no substitute for physical presence in counterinsurgency and nation-building, and that his goal was to establish a robust civilian presence throughout the country. He posted senior Foreign Service Officers to Herat, Mazar-i-Sharif, Jalalabad, Kandahar, and Helmand to manage a regional platform. Between two and six Provincial Reconstruction Teams (PRTs) - which included more junior State Department and interagency officers-would work under this platform. All of these teams worked from a provincial capital or from a military base nearby.

\section{The operating environment and Provisional Reconstruction Teams}

The nine provinces of northern Afghanistan and their approximately nine million inhabitants make up nearly one third of the country. ${ }^{2}$ The north remains the heartland for Afghan Tajiks, Uzbeks, and Turkmen. There are also "Pashtun belts" in some parts of the north, which remain a constant source of instability because of their tendency to support local Taliban groups. Due to a constellation of cultural, military, and geographic factors, northern Afghanistan has traditionally had a strong natural alignment with the United States. In general, the region was relatively secure when I arrived in Mazar-i-Sharif in 2012 and was less supportive of insurgent activity. It was a giant "ink-spot" of stability, to use a counterinsurgency theory analogy.

The German Bundeswehr (German Armed Forces) led the International Security Assistance Force's (ISAF) Regional Command North at Camp Marmal just outside Mazar-i-Sharif. The base was a collection of international diplomats, soldiers, and contractors who contributed to build partner capacity and combat terrorism. The camp included 3,000 German soldiers, 4,000 American soldiers, and 1,000 soldiers from 14 other countries. The United States provided "enablers"- primarily intelligence support and aviation-for the coalition force and a sprinkling of officers throughout the Regional Command North staff, including the deputy commander.

While the military constituted the largest component of the international mission in the north, officials from other agencies contributed to the development of Afghanistan's economy, security, and governance. Due to the challenging security environment, these other agency officials were partnered with military personnel to create PRTs, "an interim civil-military organization designed to operate in semi-permissive environments usually following open hostilities."3 PRTs improve stability by "helping to build the host nation's capacity; reinforcing the host nation's legitimacy and effectiveness; and bolstering that the host nation can provide security to its citizens and deliver essential government services." ${ }^{4}$

The first PRT was established in Gardez in 2002 and expanded into Bamyan, Kunduz, Mazar-i-Sharif, Kandahar, and Herat throughout 2003. ${ }^{5}$ When I arrived in Afghanistan in 2012, there were nine coalition PRTs in northern Afghanistan (see Figure 19.1). The size of the civilian component of each PRT varied, but in the north, it was generally between 6-20 individuals. The civilian side of the team came with special 


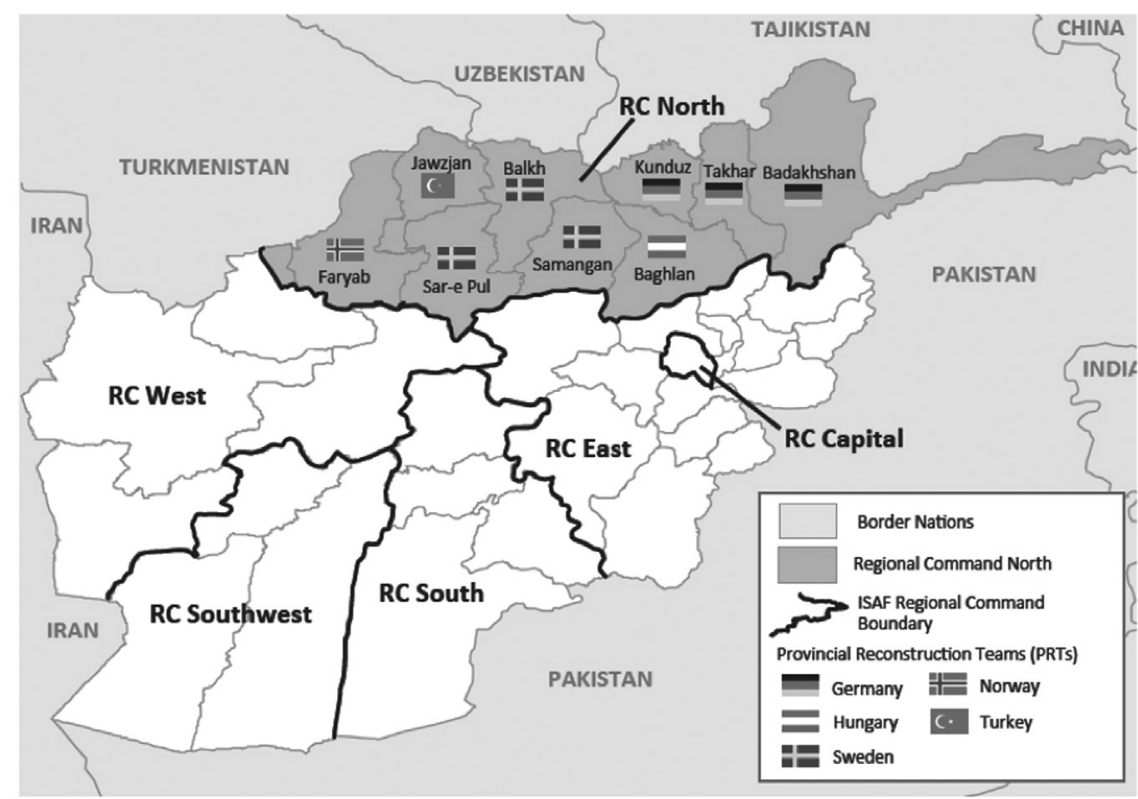

Figure 19.1 Map of PRTs in northern Afghanistan, $2012 .^{6}$

Source: Christian Karsner and Sarah Kopczynski, “Through and With: Reintegration in Northern Afghanistan,” Special Warfare 25, no. 1 (2002): 37.

skills in agriculture, economic development, justice and the rule of law, and political stability and was charged with building host country institutions and administering economic and development assistance.

The PRTs were located on military bases, with the host military unit providing base security, conducting counterinsurgency operations, and training or advising local security forces. A military commander was generally the overall leader of the PRT, and the civilian component fell under his authority. ${ }^{7}$

In addition to the international contingent, a U.S. civilian team consisting of a State Department political or economic officer, an agricultural advisor, and a U.S. Agency for International Development (USAID) program officer joined their European counterparts but worked separately from them-in practice, a PRT within a PRT. While they lacked "unity of command," they maintained "unity of effort."

They were positioned with Norway in Faryab, Sweden and Turkey in Jowzjan, Sweden in Mazar-iSharif, Germany in Kunduz and Badakhshan, and Hungary in Baghlan. They conducted political and economic reporting and engagement; public outreach; agricultural assistance; rule of law support; and assistance programs in education, health, infrastructure, and governance. The local officials found it reassuring to know that the United States remained invested in areas under the control of other NATO partners.

The U.S. teams were all well received by their European and Afghan hosts, who welcomed all the help they could get, especially when they came with project or budgetary support. Sitting atop the six U.S. PRTs was an interagency regional headquarters team that I led consisting of officers from the State Department, USAID, and the Department of Agriculture. In addition to overseeing the efforts of American PRTs, I provided senior U.S. political engagement with the governors and other prominent Afghan leaders and conducted extensive public outreach to explain the overall effort to the Afghan populace within Regional Command North.

At the national level, however, there were questions with the PRT construct, and Afghan President Hamid Karzai himself had become critical. In February 2011, Karzai raised a question in a NATO forum as to whether these "parallel structures" should be ended. ${ }^{8}$ The notion undoubtedly had its genesis 
in something Karzai had experienced, possibly a PRT that overstepped its bounds or an honest feeling that after 10 years, the local governments should be more functional.

Afghan governors, however, did not share Karzai's sentiment. They knew that PRTs were always intended to be temporary and their withdrawal, euphemistically described as "transition," would begin in 2012. One governor described the imminent pullout of the PRT as his "Y2K." He recognized the value of the PRT serving as a backstop for the provincial government when it stumbled, especially in emergencies, and in mentoring and training government officials in technical fields such as budgeting. The PRT's military component also actively worked with local security forces to ensure stability, providing a higher level of intelligence support and operational planning. The governor was in no hurry to see it end.

Nurturing cooperation in this environment required infinitely more time and patience than in a setting where one understood intuitively the players and their motivations. Nevertheless, many PRTs effectively delivered stability and progress. Success was achieved through good cross-cultural skills, empathy for the positions of others, some joint projects that bound the various foreign and host country elements together, and an effective force that was known but not visible, all under good civilian and military leadership.

\section{The economy}

The three broad lines of effort in State Department planning for stabilization, as in most similar operations, were economic development, security and the rule of law, and governance. Of the three, my team believed the economic piece to be the most urgent.

Afghanistan needed a stable economy prior to the impending coalition departure or risked what one governor described as a "fiscal and economic cliff." One researcher noted that most Afghans "judge the country's contending powers in terms of their ability, or inability, to improve the economic lot of ordinary people. ... An awareness of economic progress will do more than anything else to advance political stability." 10 Every member of the international team in the north understood the urgency of building a sustainable economy that could outlast the coalition presence. Silver bullets did not exist; instead, a long slog was required.

Progress in Afghanistan from my first tour in 2002 to my return in 2012 had been dramatic: the number of children in school had grown from one million boys to 4.6 million boys and 2.9 million girls, ${ }^{11}$ access to health care had increased from $9 \%$ to $57 \%,{ }^{12}$ gross domestic product (GDP) had increased from $\$ 4$ billion to $\$ 20$ billion with growth averaging more than $17 \%$ a year, ${ }^{13}$ mobile cellular subscriptions had increased from 25,000 to over 15 million, ${ }^{14}$ and life expectancy had increased by $9 \% .{ }^{15}$ While impressive, the gains were the result of starting from a very low bar and remained tenuous, and some, like GDP growth, were the product of unsustainable foreign investment. Still, when I showed these metrics to my Afghan counterparts, even the most skeptical official found them difficult to challenge.

Our strategy was to build a self-sustaining export-oriented economy that was organized in the short term around agricultural derivatives and transportation while simultaneously working to develop the north's more lucrative mineral wealth that could underwrite higher-level progress. The Department of Agriculture advisors, typically farmers or extension agents, ${ }^{16}$ focused on training farmers, spreading new techniques, assessing agricultural potential, steering infrastructure projects dealing with irrigation, and helping connect farmers with markets and their own government. ${ }^{17}$

State Department economic officers provided reporting to guide resource allocation and programs while engaging with local business partners. USAID directed infrastructure projects and private-sector development as well as support for governance, health, and education. The Pentagon-run Task Force for Business Stability Operations led a parallel operation intended to quickly reduce unemployment, stabilize the economy, and attract foreign investment. ${ }^{18}$

U.S. military units also supported economic development through the Commanders Emergency Response Program, which enabled "local commanders during contingency operations to respond . . . to 
urgent, small-scale, humanitarian relief, and reconstruction projects and services that immediately assist the indigenous population within their area of responsibility." 19

Given the centrality of agriculture to the economy, we hoped to expand agricultural production and build an export-oriented economy that would employ the most people across the longest employment chain. There were serious hurdles to getting products into international markets where they would draw the biggest yield: transit challenges, phytosanitary issues, lack of investment capital, poor infrastructure, and the absence of a marketing culture. Nevertheless, there were several early successes in fruits and nuts and some non-agricultural products, including carpets and skins.

Other sectors of the economy were similarly challenging, but teams found creative ways to spark development. Mazar-i-Sharif was a hub for transit across Afghanistan, and Balkh Province- of which Mazari-Sharif serves as the capital—was the country's gateway to Central Asia and Europe, a key part of the "New Silk Road" concept. By piggybacking on the military's redeployment scheme, which required the development of a world class "port" and rail line in Hairaton, a town on the Uzbek border, this transit hub could anchor the local economy.

The project brought in additional players: U.S. Army logisticians and a small team of border experts from the U.S. Department of Homeland Security's Border Management Task Force, who mentored, trained, and advised the Afghan team in effective border management. The crossing looked more and more functional each month.

Underground natural resources were more pieces of the economic puzzle. They included 59 trillion cubic feet of natural gas reserves; 1.9 billion barrels of crude oil ${ }^{20}$ and a smattering of gold, aluminum, iron, and other precious minerals conservatively estimated at $\$ 1.5$ trillion. ${ }^{21}$ They offered the promise of jobs, tax revenues, and other economic development that follows from resource extraction development. USAID and the Pentagon's Task Force for Business Stability Operations worked in parallel to develop the natural gas fields, which had thrived under the Soviet Union..$^{22}$ The overall project continues today, with Turkish investment and some progress, albeit still years away from reaching its full potential. ${ }^{23}$

There were also a handful of highly functional factories in the north, primarily around Mazar-i-Sharif. The Sadat bottling factory employed more than 100 workers and produced thousands of bottles of water daily under an extremely talented chief executive officer who had spent years abroad and operated at a level commensurate with any Western executive. The Ghazanfar brothers had built up an impressive business focused on fuel delivery, refining, and real estate. The biggest issue for both, along with other businesses that had grown up alongside them, was their dependence on a substantial international presence. They were attempting to transition to an Afghan-only economy, but it was not clear how it would be sustained when the tens of thousands of coalition members departed.

Elsewhere across the north, when advising economic development, we often found efforts lacking at least one critical component. I spent several days in Baghlan Province and found that their agricultural sales were constrained because of a lack of cold storage. Cold storage was not available because of a shortage of electricity. Electricity was not available because the dam in Pul-i-Kumri was functioning at a quarter of its capacity since the Ukrainian-built turbines broke down years earlier and the company that produced them went out of business. There was no specific culprit, just a very broken infrastructure and a mishmash of actors and interests that rarely aligned with a clear track record of production and marketing. Our teams did what they could to piece it all together.

The Afghan government, which would soon have full responsibility for economic development, was an energetic partner in some provinces and indifferent in others. Governor Atta Muhammad Nur of Balkh Province was the most visionary of the northern governors, seeking new markets in India, Iran, Uzbekistan, and the Gulf. He traveled widely, just as any American governor would to develop business. Governors of most other provinces were supportive of our efforts but did little to foster the self-sustainment of their economies. 
In the spring of 2013, the minister of finance and future president, Ashraf Ghani, spoke at a conference in Kunduz about the region's development. He said the fundamental challenge facing the north was not security but jobs and suggested it was time to move beyond production to a full competition strategy that would connect producers to exporters. He reminded the audience that there was much the country could do without the international community.

When I left Afghanistan in 2013, the economic project was unfinished. I knew that once most NATO forces left in the coming years, the support on which the Afghans depended would be gone. In my final message to Washington, I judged that the modest gains we had made were all tentative and we were a long way from bringing northern Afghanistan even to the periphery of the global economy. I suggested most of our contribution could have gone better.

I also concluded, however, that it was always going to be the work of a generation, and we needed to be realistic about the limitations of what a rural, mountainous, disjointed economy with a largely rapacious leadership could bring about. In my view, it was just enough for continued development engagement. It was clear that without continued outside assistance, any residual progress would be lost.

\section{Security and the rule of law}

The development of a lasting and viable security system had been through the same ups and downs as the economy, but, like the economy, was marked by steady progress. In 2012, the north had only 3\% of the nation's security incidents, making it a "permissive" environment, but there remained dangerous areas that could unravel at any moment. Over the previous decade, the United States and other NATO member-states had invested almost $\$ 450$ million into the security force-basing infrastructure in Balkh alone. ${ }^{24}$ This investment produced training facilities and a robust logistical system, but it was all still very dependent on ISAF.

Building on a Kabul-directed recruiting and training system that provided the initial security forces, each PRT did what it could to train, advise, and mentor the forces in its sector while conducting what missions and patrolling it could within the limits of its national caveats. ${ }^{25}$ But for the most part, security remained the primary focus of the military component of the NATO mission, with the PRTs playing a supporting role. U.S. Special Operations Forces (SOF) operated throughout Regional Command North, carrying out missions to kill or capture terrorists and insurgents, as well as building local security forces through the Village Stability Operations and Afghan Local Police program.

State Department officers and SOF worked closely in most areas, knowing that they each possessed one piece of the puzzle. State Department officers had day-to-day contact with local government officials and were building a system for local governance and the economy that would create the stable environment required to improve security over the long term. SOF teams, for their part, operated in places where State Department officers could only access with great difficulty, and they knew the local political structure and its key power brokers. SOF and State Department officers exchanged information, synchronized strategies, and often found places where their direct cooperation could make a difference between success and failure.

I saw this play out even more clearly in Anbar Province in Iraq on a previous deployment. As a division of labor, I managed the formation of the new provincial government, and a team from the Central Intelligence Agency engaged with tribes who were losing influence with the current local leadership, while SOF teams contained nefarious actors. We met frequently to compare notes and share information. When it became clear to the intelligence team that one major tribal grouping was left behind in the provincial government formation, I struck a deal with the other members to include them, while the SOF teams kept potential spoilers at bay through direct action raids. It was one of the clearest examples of positive unity of effort I have seen.

In the north, containing spoilers was one primary mission for SOF, and the diplomats helped build trust and relationships with local strongmen and leaders to ensure they understood the purpose of the SOF raids 
and helped mitigate blowback when a "night raid" went awry. Based on our extensive relationship building, the local governors greatly appreciated the SOF raids. I asked several governors what they would select if they had to choose among a one-year extension of the PRT, $\$ 1$ million for their security forces, or an indefinite extension of night raids. They invariably opted for night raids. They knew the Afghan national forces could not confront and control the terrorist threat alone, and they accepted the occasional fallout from collateral damage.

In the midst of these efforts, the Afghan National Army, Afghan Border Force, and Afghan National Police made progress. In March 2013, to ensure a safe Nowruz Festival for hundreds of thousands of pilgrims coming into Balkh, Governor Atta consolidated local and national security forces in Mazar-i-Sharif under a single command, with even the Afghan National Army commanders deferring to his leadership. The event would bring hundreds of thousands of pilgrims and other visitors to his province, and he was determined to ensure it would occur without incident.

Atta assembled 6,200 security personnel from the police, border guards, and army, and developed four cordons of successively tighter security. It ran like clockwork and with no visible coalition presence. It was a good example of how the security system could come together when properly led.

Such leadership was not initially available several weeks later in Badakhshan Province. A band of insurgents - a curious mix of criminals and religious extremists - in the Wakkan corridor ambushed an Afghan army column, killing more than a dozen soldiers. ${ }^{26}$ The attack set off a month-long scrum by the army and police to re-establish their presence in some of the country's toughest terrain and laid bare the security forces' lack of cohesion, planning skills, morale, air power, and leadership. Above all, it raised questions about the division of labor, with the army wanting to be the "clear" force to the police's "hold" force but the police arguing they lacked capability to hold anything. To their credit, the security forces collectively clawed their way back in and reestablished the government's presence.

Across the north, the security forces adjusted to changing conditions. The Afghan army came in when called, and they largely muddled through. The local PRTs took more and more of a hands-off approach but tried to support the force with training, advising, and mentoring, increasingly staying out of the perpetual appeals for logistical support, something the Afghans never quite mastered.

One perpetual problem was that the national security system was never able to fully overcome the local security architecture that had existed for so long under warlords, strongmen, and ethnic leaders. These leaders maintained their private security forces through either informal or formal networks, and there was continued space for insurgent groups to operate. ${ }^{27}$ The governor of Faryab Province told us he was in a "bidding war" with insurgent leaders for the loyalty of the province's young men. The governor of Talibanheavy Baghlan Province conversely believed that the police worked for money, while the Taliban worked for faith, claiming that "100 Talibs could overcome 1,000 police."

It was a continuing struggle to establish the primacy of the national government throughout the country, not unlike what Colombia has largely achieved after its nearly 50-year fight with the Revolutionary Armed Forces of Colombia. Establishing governance and security in a rugged nation like Afghanistan or Colombia is often a resource-intensive, lengthy, and bloody battle.

One of the programs the United States and the United Kingdom implemented to overcome this lack of security in the countryside was the Afghan Local Police, a federally funded local force for rural areas that many worried would become just another armed group. State Department officers often worked closely with SOF teams who conducted the training mission to ensure a tribal balance and good political landing for the new force.

Beyond investing in the development of Afghan security forces, several countries, notably the Netherlands but also the United States, had modest programs for rule of law and judicial support. In most of the provinces, we found that there was some NATO investment in improving judicial systems in the provincial capital but little in the districts. The supporting U.S. effort funded a network of advisors and defense 
attorneys and attempted to improve both the quality of the judicial system and the ability of the police, courts, and other local officials to coordinate their actions through better case management.

There were the occasional cases where the system worked, including in June 2012, when four Afghan Local Police members received sentences of 16 years in prison for the rape of a young girl. ${ }^{28}$ Unfortunately, this was the exception. Many Afghans turned to the Taliban to seek justice from the predations of local strongmen. Sustaining the new system would be difficult, and we knew we were only working on the margins.

Corruption was one of the many negative outcomes resulting from a poor judicial system - the one constant across most sectors and provinces. Unfortunately, corruption actually worsened over time. When Transparency International first ranked Afghanistan on its corruption perceptions index in 2005, it ranked 117 out of 159. By 2012, Afghanistan had fallen to 174 out of 198 and has failed to improve since. ${ }^{29}$

Sarah Chayes, who spent years in Afghanistan and became one of the leading voices on corruption, said in a 2015 interview after a trip to Kunduz: "In an arid place like Afghanistan, almost entirely dependent on high-end agriculture . . stealing someone's land is worse than murdering them." The ability of local strongmen to take land, she went on, means that "years of built-up grievances and no avenue of recourse drive people to extremes," with a "thoroughly corrupt" government implicated on the wrong side of the issue. ${ }^{30}$

We did what we could with local authorities to support anti-corruption programs, one of which was run by Shamshullah Jawid, the head of the local Afghan High Office of Oversight and Corruption. Jawid was part of the new class of bureaucrats in the government, not connected through birth or tribe to power but hopeful of having influence through professionalism, technical competence, and fairness. He was working on an awareness campaign that had reached 2,700 people through seminars and conferences and had dozens of ongoing corruption cases. ${ }^{31}$

The security forces and the judiciary still had a long way to go. Yet in 2013, a rudimentary infrastructure was in place, a new generation of leaders had been trained, and with political will and consistent outside resources, continued progress was conceivable. Of the two, the judiciary was to be the most difficult, and we knew it would likely end up with a much more localized flavor.

\section{Governance}

Nadia Schadlow noted that "to wage war effectively, civilian and military leaders must operate as successfully on political battlefields as they do on the physical." ${ }^{32}$ Fareed Zakaria added that "in almost every situation that U.S. forces are involved in, the solutions are more political than military. . . Military force without a strategy or deeply engaged political and diplomatic process is destined to fail." 33

Getting regional warlords to lay down their weapons and support a national government was at the center of Afghanistan's many transitions. One key factor was the traditional disconnect between the central government and the regional and local governments in Afghanistan, whose tough terrain has always made strong local autonomy a political fact of life.

Both post-9/11 leaders-Hamid Karzai from 2002-2014 and Ashraf Ghani since 2014-have struggled to channel power away from regional strongmen into national institutions. They have appointed governors from outside the regions who could implement national policies independent of local actors, deployed security forces led by outsiders, alternatively withheld and offered resources, and attracted some regional leaders to Kabul with ministerial positions to take them away from their center of gravity.

But they were competing with regional strongmen who had a firm local power base that derived from various revenue streams (often from border crossings in the north), a place of prominence in their ethnic group, their martial prowess proven in the various wars of the last decades, and at times sheer brutality and thuggery. In many provinces, the regional power brokers resembled a firmly entrenched mafia family. ${ }^{34}$ 
Our challenge in dealing with these regional leaders, who could not legitimately be ignored and who on matters of security and counterterrorism were often active on the right side of the equation, was how to bring them under the national umbrella. We did so by engaging them actively and respectfully but channeling all our resources through the representatives of the central government.

By 2012, the reality of the impending transition from NATO to Afghan forces, which would occur in phases between 2013 to 2015, when only a residual force at Camp Marmal would be left across the north, began to sink in for local leaders. I found this in a visit to Abdul Rashid Dostum, the Uzbek leader who had fought with the United States in ousting the Taliban. Over a lavish lunch in his compound in the spring of 2013, Dostum showed us a large map with his electoral strategy for the 2014 election. He summed it up by saying "the election is the new AK for the Afghan family." ${ }^{5}$ From here on out we will fight through politics, not force, he suggested.

It would be a long road for the government to consolidate power, knowing that the strongmen would maintain their informal networks of influence even as they cautiously supported the developing formal government networks. The hope was that leaders like Dostum would move away from militias and toward the transparent amassing of wealth, media influence, and coalition building, paving the way for a postwarlord society.

The electoral system since then has become more decentralized. For the first time, voters chose district councils in 2018 that had some resources and authority retained locally, as opposed to the prior system of pushing all electoral energy to Kabul with resources returning at the discretion of the federal government. Against this backdrop, governance capacity at the provincial level progressed slowly if unevenly. The centrally chosen and placed governors in many cases were quite capable and connected to their province, especially if they were from the area and not sent from Kabul to quell any moves toward autonomy.

The provincial and local levels were less capable, however, and international donors sought to help develop a rudimentary capacity to budget, plan, and deliver services. Military civil affairs units also stepped into the breach, often bringing critical skill-sets that were not otherwise available for training, advising, and mentoring a local civil service. Local officials generally accepted the assistance as long as it was respectfully delivered and consistent.

Effective PRTs realized that they were key political players themselves and therefore needed to devote resources and effort to building their own influence. But with 9,000 villages and very little television and internet penetration in the north, it was a challenge. We decided radio would be our best tool, and several local stations that were tired of the poor international perception of Afghanistan were open to our more positive message. We fed them a steady stream of interviews and events.

We messaged especially heavily on the transition issue, which we saw as a game of confidence. Left to their own devices, few Afghans seemed to believe that they could develop into a functional democracy and market economy, but with the continuation of some form of international support, they saw the odds shifting in their favor. I believed we needed to be visible, present, and proactive.

As diplomats and soldiers conducted engagement, religious leaders were also high on the list of those to be engaged. In early November 2012, a negative video about the Prophet Muhammad was about to be published on the internet, and we wanted to stave off a violent reaction. The previous year, protesters overran a United Nations compound in Mazar-i-Sharif, killing seven employees after an obscure pastor burned Qurans at his Florida church. ${ }^{36}$

I met with the governor and both of the Sunni and Shia imams to warn them of the imminent video release, and the imams promised to do their part. The Sunni imam, having spent time in Kentucky on a State Department program, promised to take a firm message to the mosque that this single incident did not represent the American people he had come to know. Governor Atta was similarly determined not to allow another round of violence over the incident, and he directed the security forces to ban demonstrations outside of compounds. 
It reminded us again of the criticality of local leadership but also of taking the time to develop the relationships that would ensure that Afghan leaders remained on our side. There is no substitute for faceto-face encounters and for experiencing American culture firsthand.

Both local and national politics continued to progress, albeit unsteadily, but the real test of their progress, as with the economy and security forces, would be the withdrawal of the bulk of the international force across the sector during 2013-2014.

\section{Transition: a testing of what the partnership yielded}

From the day I arrived, one of our primary objectives was preparing for "transition," which required handing over security responsibilities to Afghan forces and political responsibilities to local officials. Regional Command North Commander Major General Vollmer likened it to conducting a "relief in place"-turning over bases and operating space to Afghans while in many cases under fire. I recall him reminding his staff that this was one of the most difficult missions a unit can conduct, directing that we would go out with our heads held high, not rushing to the door, but not lingering.

In October 2012, several NATO ambassadors held a discussion in Mazar-i-Sharif with local governors and security commanders. The message of the Afghans was one of a vast unfinished project that was on track but needed continued attention and resources to conclude successfully. They stressed the importance of ongoing support to the security forces but even greater importance to a steady flow of development assistance that would lead to jobs and poverty reduction.

The closure of PRTs was one of the most visible parts of the transition. Over the course of eight months in late 2012 to 2013, the Norwegians, Swedes, Germans, and Hungarians decamped nearly every PRT. By the summer of 2013, the only PRT remaining in the north was at Mazar-i-Sharif. Even with months of preparation, the process was inconsistent. In November 2012, well into the transition, one senior allied military advisor told me, "when we take the training wheels off, we sometimes find there wasn't a bicycle there to begin with."

In some provinces, we were not sure what would happen after the PRTs withdrew, because it was extremely difficult to assess the PRT's impact. In many places, international forces had stopped actively patrolling months ahead of the withdrawal, and in some cases, their national "caveats" had prevented them from ever having conducted combat operations anyway. But it soon became apparent that the mere presence of an international force, and especially of NATO SOF, had positively impacted security.

The early withdrawals went well enough, and some violence was expected. For example, in October 2012, a suicide bomber killed 45 people at a mosque in Maimana, the capital of Faryab Province. ${ }^{37}$ In some districts in Baghlan Province, the Taliban's "shadow government" squeezed out the poorly financed legitimate government and outmatched its security forces. The continued corruption and the predatory nature of some local officials also pushed some citizens to view the Taliban as the lesser of two evils. ${ }^{38}$

The Taliban strategy involved more than just being marginally less corrupt; they had been building a multi-ethnic coalition including Hazaras and Tajiks and presented a softer touch than the previous Taliban regime.

Our challenge was devising a way to keep our presence visible enough to support the Afghans in the transition after the withdrawal of military forces. In a January 2013 report to the embassy, I offered that "the Afghans are slowly gaining confidence in their own abilities, but always with a backward glance to see that we are still with them." I suggested that "the United States can play a decisive supporting role in maintaining the generally positive trajectory of the north, but only if we are here. . . We need to be visible, present, and engaged." 39

We explored several ways to remain engaged, at least with some peripheral tasks, including key leader engagement, support for the rule of law, anti-corruption efforts, and economic development, even if carried out through local partners with only occasional face-to-face encounters. Yet after the unfortunate 
politicization of the Benghazi incident, there was little appetite to assume the risk that would have been required for even such indirect engagement. In the end, the Afghans started to realize that in most places, transition meant withdrawal.

\section{Conclusion}

As I left Mazar-i-Sharif, I wrote to Kabul that the ball was still much in play in the north. Without our continued focus, however, it could quickly end up out of bounds or more likely somewhere in the bleachers. In a final cable, I concluded:

In urban areas there is a post-warlord political culture developing that is being buttressed by a postwar generation to create exciting new possibilities for the future. But rural areas, especially those that are cut off geographically from cities, are not part of this progressive picture, and even some more connected areas such as Kunduz are still at the mercy of the guy with the most shooters. The [Afghan National Security Forces] has its work cut out for it, and will need to pick up the pace if it is not to be outrun by the devolving security environment. Economically we are seeing the fruits of 10 years of rebuilding but increased agricultural and physical production must now be matched with internal and external markets to create jobs, something that will require extensive international assistance. The United States and the international community continue to play a vital role in all this both through continued direct assistance, and through beating back the chilling narrative of abandonment. ... Going forward, showing up will be at least half the job here.

It was a bit on the optimistic side, although I sensed that pessimism was in such rich supply that there was no point in adding to it. In the end, the setbacks have been worse than I would have thought, while the progress has been less obvious. Still, it would be impossible to write the project off just yet. The Afghan National Security Forces continue to make progress, and hundreds of Afghans feel strongly enough about their country to give their lives in its defense. Elections, imperfect as they are, continue to yield democratically elected leaders. Education continues to edge along, and health care is ever improving.

The roots for economic progress are in place. The lesson might be that it is simply hard to pull a severely underdeveloped country into the modern age. But it is nearly guaranteed to fail without continued focus and resources from the international community, and given the threats emanating from ungoverned spaces of late, it may be worth staying the course. Adapting U.S. government architecture for engagement to draw out the skills and resources of the American interagency at the proper level and for the appropriate amount of time will be essential to success.

\section{Notes}

1 Department of the Army, Insurgencies and Countering Insurgencies, FM 3-24 (Washington, DC: Department of the Army, 2014), 7-9.

2 Bijan Omrani and Matthew Leeming, Afghanistan: A Companion and Guide (Hong Kong: Odyssey Books and Guides, 2011), 234.

3 Center for Army Lessons Learned, Afghanistan Provincial Reconstruction Team: Observations, Insights, and Lessons (Fort Leavenworth: U.S. Army Combined Arms Center, 2011), 1.

4 Ibid.

5 Ibid., 3.

6 Christian Karsner and Sarah Kopczynski, "Through and With: Reintegration in Northern Afghanistan," Special Warfare 25, no. 1 (2002): 37.

7 The Swedes, wanting to emphasize the primacy of the civilian effort, put an ambassador in charge of both the military and civilian components in their sector. 


\section{Stabilization in Afghanistan}

8 Judy Dempsey, “Karzai Seeks End to NATO Reconstruction Teams,” New York Times, February 6, 2011, www. nytimes.com/2011/02/07/world/asia/07munich.html.

9 Y2K, short for the year 2000, referred to the computer shortcut that was expected to wreak havoc when the year changed from 1999 to 2000.

10 S. Frederick Starr, Finish the Job: Jump-Start Afghanistan's Economy, a Handbook of Projects (Washington, DC: CentralAsia Caucasus Institute Silk Road Studies Program, 2012), 11.

11 "Education in Afghanistan," World Education News \& Review, September 6, 2016, https://wenr.wes.org/2016/09/ education-afghanistan; UNICEF, UNICEF Annual Report 2012 for Afghanistan (New York: UNICEF, 2013$), 2$.

12 "Afghanistan Health Sector Fact Sheet," U.S. Agency for International Development, accessed October 30, 2020, www.usaid.gov/sites/default/files/documents/1871/AFG\%20Health\%20Sector\%20Fact\%20Sheet $\% 20$ FINAL $\% 20$ 06.14.2014.pdf.

13 “Afghanistan," World Bank, accessed October 30, 2020, https://data.worldbank.org/country/AF.

14 Sam Gollob and Michael E. O’Hanlon, Afghanistan Index (Washington, DC: Brookings, 2020), 36.

15 "Life Expectancy at Birth, Total (Years)_Afghanistan," World Bank, accessed October 30, 2020, https://data. worldbank.org/indicator/SP.DYN.LE00.IN?locations=AF.

16 An extension agent is an agriculture expert and mentor.

17 The agricultural advisors were among the most effective, best exemplified by the simple statistics of the wheat harvest, which had increased from an average of 2.67 million metric tons in 2002 to 5.0 million metric tons in 2012. Although good rains played a part, it also had much to do with the advisors overseeing the systematic replacement of the wheat seed across the country to develop a more resilient and higher yielding strain. See "Afghanistan: Wheat Production Quantity," Knoema World Data Atlas, accessed December 10, 2020, https://knoema.com/atlas/ Afghanistan/topics/Agriculture/Crops-Production-Quantity-tonnes/Wheat-production.

18 S. Rebecca Zimmerman, Daniel Egel, and Ilana Blum, Task Force for Business and Stability Operations (Santa Monica: RAND, 2016).

19 Department of the Army, The Commanders' Emergency Response Program, ATP 1-06.2 (Washington, DC: Department of the Army, 2017), 1-1.

20 Amie Ferris-Rotman and Ramya Venugopal, “Exxon Explores 'Very Promising'Oiland Gas Fieldsin Afghanistan,”Reuters, September 7, 2012, www.businessinsider.com/this-energy-company-hopes-to-find-oil-in-afghanistan-2012-9.

21 Eltaf Najafizada, "Study Finds Mineral Deposits Worth \$3 Trillion in Afghanistan,” Bloomberg, January 29, 2011, www.bloomberg.com/news/articles/2011-01-29/u-s-afghan-study-finds-mineral-deposits-worth-3-trillion.

22 Amity Shlaes, "Afghan Resources Flowing to U.S.S.R. Despite the War; Hungary Seeks Dollars," Wall Street Journal, January 17, 1984.

23 Shadi Khan Saif, “Afghanistan Starts Gas Extraction After 4 Decades,” Anadolu Agency, April 2, 2020, www.aa.com. tr/en/asia-pacific/afghanistan-starts-gas-extraction-after-4-decades/1789496.

24 This number is based on the author's recollections from a meeting with a member from the U.S. Corps of Engineers in Afghanistan in 2012.

25 The Hungarian forces in Baghlan, for example, were prohibited from firing weapons except in self-defense, and most NATO allies had similar restrictions, often extremely detailed. See Regeena Kingsley, Fighting Against Allies: An Examination of 'National Caveats' Within the NATO-Led International Security Assistance Force (ISAF) Campaign in Afghanistan and Their Impact on ISAF Operational Effectiveness, 2002-2012, Volume II: Appendices (PhD diss., Massey University, 2014), 125, https://mro.massey.ac.nz/xmlui/bitstream/handle/10179/6984/03_appendices. pdf? sequence $=4 \&$ is Allowed $=\mathrm{y}$.

26 Rod Nordland, “Taliban Kill 17 Afghan Soldiers in Once-Quiet Region,” New York Times, March 6, 2013 , www. nytimes.com/2013/03/07/world/asia/taliban-kill-17-afghan-soldiers.html.

27 Dipal Mukhopadhyay, Warlords, Strongman Governors, and the State in Afghanistan (New York: Cambridge University Press, 2014).

28 Jawad Sukhanyar and Alissa Rubin, “4 Members of Afghan Police Are Found Guilty in Rape," New York Times, November 7, 2012, www.nytimes.com/2012/11/08/world/asia/afghan-militia-members-found-guilty-in-rape.html.

29 "Transparency International Corruption Perceptions Index," accessed November 10, 2020, www.transparency.org/en/.

30 Theresa Riley, "Sarah Chayes on Why Afghanistan Is Going to Fall to the Taliban Again," Moyers and Company, Perspectives, October 5, 2015.

31 Based on the author's notes from conversations with Shamshullah Jawid.

32 Nadia Schadlow, War and the Art of Governance: Consolidating Combat Success Into Political Victory (Washington, DC: Georgetown University Press, 2017), 2.

33 Fareed Zakaria, “The United States Is Stumbling Into Another Decade of War,” Washington Post, June 22, 2017, www.washingtonpost.com/opinions/global-opinions/the-united-states-is-stumbling-into-another-decade-ofwar/2017/06/22/7cd589f2-5796-11e7-a204-ad706461fa4f_story.html. 
34 Mukhopadhyay, Warlords, Strongman Governors, and the State in Afghanistan.

35 AK refers to the AK-47 rifle, which was the most common rifle in Afghanistan dating back to the Soviet-Afghan War.

36 Mohammad Bashir, "Worst Attack on U.N. in Afghanistan Kills at Least 7," Reuters, April 1, 2011, www.reuters. com/article/us-afghanistan/worst-attack-on-u-n-in-afghanistan-kills-at-least-7-idUSTRE7306JP20110401.

37 Alissa J. Rubin and Sangar Rahimi, "Suicide Bomber Kills Dozens of Worshipers in Afghanistan," New York Times, October 26, 2012, www.nytimes.com/2012/10/27/world/asia/afghanistan-suicide-bombing.html.

38 Joseph Goldstein, "A Taliban Prize, Won in a Few Hours after Years of Strategy," New York Times, September 30, 2015, www.nytimes.com/2015/10/01/world/a-taliban-prize-won-in-a-few-hours-after-years-of-strategy.html.

39 Quarterly report from senior civilian representative RC-North to Embassy Kabul, January 15, 2013, in possession of the author. 